Jurnal ASPIKOM, Vol. 6, No. 2, July 2021, pp. 329-344

P-ISSN: 2087-0442, E-ISSN: 2548-8309

DOI: http://dx.doi.org/10.24329/aspikom.v6i2.894

\title{
Regulation Issues of Digital Broadcasting in Job Creation Law
}

\section{Masalah Regulasi Penyiaran Digital dalam Undang-Undang Cipta Kerja}

\author{
Supadiyanto \\ Sekolah Tinggi Ilmu Komunikasi Yogyakarta, J1. Laksda Adisucipto No.279, \\ Ambarukmo, Daerah Istimewa Yogyakarta, Indonesia \\ Corresponding author, e-mail: supadiyantostikomyogyakarta@gmail.com
}

\begin{abstract}
Broadcast media had become a prospective business. The practice of the broadcast media business had surpassed legislation authority, resulting in currently utilized technology unaccommodated in Law No. 32/2002 on Broadcasting. The release of Law No. 11/2020 on Job Creation to merge existing laws into a simple regulation package did not make the broadcast media industry visionary. How are the current law maps of analog and digital broadcasting in Indonesia? How is the current practice of digital broadcast media business in Indonesia? The type of research is descriptive. This study used a legal positivism approach. The data collecting technique was conducted through literature study and legal study. As for the result, the current analog broadcasting regulation complied with Law No. 32/2002 concerning Broadcasting and Law No. 11/2020 concerning Job Creation. In practice, TV stations that broadcast on digitalinternet channels did not possess a formidable legal basis.
\end{abstract}

Keywords: Analog; Digital broadcasting; Internet; Law

\begin{abstract}
Abstrak
Media penyiaran menjadi bisnis prospektif. Namun praktik bisnis media penyiaran telah melampaui kewenangan tata perundang-undangan; akibat teknologi yang dipergunakan sekarang tidak terakomodir dalam Undang-Undang No. 32/2002 tentang Penyiaran. Hadirnya Undang-Undang No. 11/2020 tentang Cipta Kerja melebur berbagai Undang-Undang menjadi satu paket regulasi sederhana; tidak otomatis menjadikan industri media penyiaran menjadi visioner. Bagaimana peta hukum penyiaran analog dan digital di Indonesia sekarang? Bagaimana praktik bisnis media penyiaran digital di Indonesia sekarang? Jenis penelitian adalah diskriptif. Kajian regulasi memakai pendekatan hukum positivistik (mengkaji regulasi bidang penyiaran analog dan digital). Teknik pengumpulan data melalui: kajian pustaka dan kajian hukum. Riset sejak Maret 2020 - Januari 2021. Hasilnya, hukum penyiaran analog tunduk pada Undang-Undang No. 32/2002 tentang Penyiaran dan Undang-Undang No. 11/2020 tentang Cipta Kerja. Praktik stasiun televisi bersiaran di kanal digital dan internet, belum memiliki landasan hukum kuat.
\end{abstract}

Kata Kunci: Analog; Hukum; Internet; Penyiaran digital 


\section{Introduction}

The revision of Law No. 32/2002 concerning Broadcasting that has been going on since 2007 until today (2020) continues to encounter total failure. The House of Representatives of the Republic of Indonesia 2004 - 2009 (Election results 2004), the House of Representatives of the Republic of Indonesia 2009 - 2014 (Election results 2009), continued by the House of Representatives of the Republic of Indonesia 20142019 (Election results 2014) were only able to deliver the bill of amendments of Law No. 32/2002 concerning Broadcasting into Priority National Legislation Program that is halted in legislative sessions. This means 13 years of the revision process that spends billion rupiahs results in nothing. In fact, the House of Representatives period 20192024 (Election result 2019) does not include the bill of revision of Broadcasting Law No. 32/2002 into Priority National Legislation Program 2020. This means the future of digital broadcasting becomes more unclear. One of the main causes of this revision failure is the issue of digital broadcasting channel management rights or also known as Multiplexer (MUX).

The enactment of Law No. 11/2020 about Job Creation on 2 November 2020, as a convergence of regulations, one of which is Broadcasting Law No. 32/2002, is considered capable of becoming legal protection in implementing digital broadcasting in Indonesia. The issuance of Law No. 11/2020 on Job Creation that is strongly rejected by several parties (lecturers, students, NGOs, Civil Society Organization, labor unions, and many more) will be a legal issue in the future. As evidence, some parties currently file a judicial review to challenge the Job Creation Law No. 11/2020 to the Constitutional Court.

Recently, MNC Group filed a judicial review against Broadcasting Law No. 32/2002 (particularly Article 1 paragraph 2) to the Constitutional Court. They demanded the definition of broadcasting as mentioned in Article 1 paragraph 2 of Broadcasting Law No. 32/2002 to be broadened, covering providers of OTT audio-visual service or internet-based digital platforms, such as YouTube, Instagram, and so on. This surely becomes an important legal occurrence for the dynamics of digital broadcast media management in Indonesia.

As of 11 March 2020, the World Health Organization (WHO) stated Coronavirus Diseases 2019 (COVID-19) as a global pandemic; this caused a remarkable impact on how global citizens consume mass media. There was an extraordinary surge in the number of internet and social media users as an impact of Work from Home, social distancing, as well as self-quarantine policies. The decline of ad revenue obtained by conventional media companies during the COVID-19 pandemic urges the companies to stipulate a strict policy by terminating their employees.

The researcher is interested in uncovering the absence of laws in digital broadcasting. Whereas technology in communication, media, and informatics develops rapidly, the digital broadcasting laws in Indonesia are slow, frail, conventional, and partial. There are two kinds of legal development strategies: orthodox/conservative/elitist and responsive/populistic. In orthodox legal development strategies, the role of state institutions (government and parliament) is very dominant in determining the direction of legal development. In contrast to the responsive legal development strategy, the role of the judiciary and the participation of social groups or individuals in society are very dominant (Mahfud, 2017, p. 29).

Here is presented the essence of previous research on the dynamics of digital broadcasting. First, the dynamics of Broadcasting Laws revision that has been going for 
over a decade but not yet accomplished. According to Mochamad Riyanto (2019, p. 60), the Broadcasting Laws amendment must be directed to encourage economic growth through the development of the broadcasting industry equipped with economic law instruments. The existence of gesture is different in broadcasting digitalization; the government delegates the administration to a broadcasting institution that possesses an operating broadcasting license. Meanwhile, the House of Representatives of the Republic of Indonesia insists that multiplexing management is delegated to multiplexing broadcasting institutions with a hybrid mux migration model (Budiman, 2020, pp. 125126). Sutanto and Alatas (2015, p. 248) stated that in arranging digital broadcasting plans, government tends to side with capital interest in determining multiplexing operators. Meanwhile, the civil society groups want MUX management to be completely left to the state (in this case LPP TVRI/RRI) with a single MUX model.

A research by Maulana (2019, p. 60) revealed that single multiplexing becomes an ideal digital broadcasting model because the government's frequency authorization will create a public realm containing balance private and public domains. Compared to the multiplexing model, single multiplexing is relatively safer from an intense debate. The sharp differences in attitudes that occurred in the House of Representatives resulted in the revision of Law No. 32/2002 on Broadcasting that has been going on since 2007 until now, yet there is no clear point.

Second, a study by Abdullah (2020, pp. 93-94) confirmed that broadcasting digitization practice in Indonesia does not have a clear regulation after the Decree of Minister No. 22/2011 was revoked by the Supreme Court of the Republic of Indonesia. It means that before the issuance of Law No. 11/2020 on Job Creation, there was a vacuum in digital broadcasting law. However, so far, the Minister of Communication and Information Technology of the Republic of Indonesia has only based the regulations at the level of a Ministerial Regulation to determine policies regarding digital broadcasting. Third, the research finding by Ramli (2008, pp. 10-11) concluded that the development of telecommunication technology must be balanced with the regulation system that is capable of giving legal certainty and social justice to society. Therefore, the release of Law No. 11/2008 on Information and Electronic Transaction (later revised through the issuance of Law No. 19/2016) becomes a breakthrough and an important part of controlling cyber law.

Fourth, a study by Sumiaty (2012, p. 222) stated that Law No. 32/2002 on Broadcasting is advisable to be revised, and the authority of the Indonesian Broadcasting Commission (KPI) should be reinforced. Fifth, Armando's (2019, pp. 5657) research emphasized that the failure of the private television network broadcast system in Indonesia is influenced by a lot of factors, mainly affected by the relationship of power that creates a communication resource. From several parties that battle in the implementation of the Network Station System, the capitalist party of the networked private commercial television station is consistent in defending their interest by thwarting Network Station System implementation. The other three parties are very dependent on context and involved persons. This matter is also relevant with the study by Nainggolan $(2018$, p. 781$)$ that domination of the national television market by three giant media, including Global Mediacom, EMTEK, and Visi Media Asia leads to less competitive market competition.

Sixth, Djulaeka and Jusmadi (2013, p. 59) emphasized the importance of evoking telematics convergence regulation that can control current telematics convergence. Seventh, Ernawati (2020, p. 52) criticized the plan for an Indonesian Broadcasting 
Commission's new policy related to its plan to supervise digital content on Netflix and YouTube that obtained a negative response from public. This research finding indicates that in the state administration system, the Indonesian Broadcasting Commission (KPI) does not have the authority to supervise new digital media. Revision of Broadcasting Law is needed so that KPI's authority can be broadened.

Eighth, the research by Maulana and Hasfi (2019, p. 179) is relevant to become a conceptual foundation in this research. It concludes that the single multiplexing model in digital broadcasting management is considered the most appropriate since the government is the administration operator of digital broadcasting multiplexing. Ninth, Yuniarto $(2019$, p. 6) revealed that the presence of the $5 \mathrm{G}$ network allows the audience to obtain various information rapidly. For information and news providers, this network can increase content types and forms that are produced and traded freely.

Numerous studies concerning issues of partial digital broadcasting have been studied by the aforementioned researchers, yet as of this moment, no research comprehensively analyzes the absence of digital broadcasting regulations. The issuance of Law No. 11/2020 concerning Job Creation, which includes regulations on digital broadcasting in general, can be a legal leap to fulfill the absence of regulation for over 18 years. The excellence of this research is that it analyzes the existence of digital broadcasting regulations related to the issuance of Law No. 11/2020 on Job Creation and revision of Law No. 32/2002 on Broadcasting that has not finished yet.

Research on digital broadcasting regulations and dynamics is limited. Therefore, this research is conducted to unveil facts and events related to digital broadcasting. There are two main problems in this research. First, how are the current law maps of current digital and analog broadcasting in Indonesia? Second, how is the current practice of the digital broadcast media business in Indonesia?

\section{Method}

The type of this research is descriptive. The regulation study uses a legal positivism approach by gathering data related to regulations and legislation controlling the digital and analog broadcasting industry. The data collecting technique was conducted through literature study, observation, interview, and legal study as well as the reflection of the researcher's experience. Data were processed by analyzing all data entries that were obtained selectively to draw the conclusion. This research was conducted from March 2020 - January 2021.

\section{Results and Discussion}

\section{Analog and Digital Broadcasting Law Maps in Indonesia Remain Overlapping}

A new chapter of digital broadcasting administration in Indonesia is wide open along with the issuance of Law No. 11/2020 concerning Job Creation on 2 November, 2020. After the absence of regulation in digital broadcasting for over 18 years, the presence of Law No. 11/2020 on Job Creation feels like an oasis in the desert despite being general and global. The shortage of this law is that it cannot respond to a range of problems in digital broadcasting industry management in a complex manner.

As is widely known, several elements of society (students, lecturers, Civil Society Organization, and others) staged protests against Job Creation Law in various cities in Indonesia. According to Law No. 11/2020 on Job Creation, regulation on the broadcasting industry is only controlled through Article 60A paragraph 1-3. Paragraph 1: Broadcasting administration is conducted by following technology development, 
including broadcasting migration from analog to digital technology. Paragraph 2: Terrestrial television broadcasting migration from analog to digital is referred to in paragraph 1, and analog switch-off is completed no later than two years from the enactment of this law. Paragraph 3: Further provisions concerning broadcast migration from analog to digital technology, as referred to in Paragraphs 1 and 2 are regulated in the Government Regulation.

According to the article above, it has been clearly stated that the migration of analog-based to digital-based broadcasting is targeted to be completed no later than 3 November 2022, or 2 years after the stipulation of Job Creation Law No. 11/2020. The biggest issue encountered by broadcast media industry operators is their readiness to adopt digital broadcasting technology. This is because analog broadcasting that has been spending a huge investment will be terminated.

Furthermore, society's readiness to possess digital televisions also becomes an issue. Despite the analog televisions they have been using so far can pick up digital television broadcasts, they have to use a converter known as Set Top Box, which is rather costly. The most crucial problem in digital broadcast media industry management is Multiplexer (MUX) management, which has been an intense dispute between broadcast media industry managers, the House of the Representatives, the government, and the public from 2007 until today. The failure in revising Law Broadcasting No. 32/2002 always becomes a scourge when discussing this complicated issue.

There are three opinions in response to this substance. First, MUX management is completely delegated to a networked Private Broadcasting Institution which has been seasoned in managing broadcasting technology. This opinion related to multi MUX received a remarkable rejection from the operators of the local television industry for it does not give equity and equality in the opportunity to obtain MUX transparently. History records that the Association of Indonesian Network Television and the Association of Indonesian Local Television have filed a legal lawsuit against the Regulation of Minister of Communications and Informatics No. 22-PER-M.KOMINFO11-2011 on Free-To-Air Digital Terrestrial Television Broadcasting Administration to Civil Court in East Jakarta, in which their lawsuit is granted.

In fact, the Supreme Court of the Republic of Indonesia has repealed the Regulation of Minister of Communications and Informatics No. 22-PER-M.KOMINFO11-2011 on Free-To-Air Digital Terrestrial Television Broadcasting Administration through Decree No. 38 P/HUM/2012 and Decree No. 40 P/HUM/2012. The Supreme Court evaluated that the Regulation of Minister of Communication and Informatics has been proven contradictory to the philosophy embodied in Law No. 32/2002 concerning Broadcasting and Government Regulations No. 50/2002 on Administration of Private Broadcasting Institution. Another series of the historical record is in trial No. 119/G/2014/PTUN-JKT: the Civil Court of East Jakarta on 5 March, 2015 has repealed 33 Decrees of Minister of Communication and Informatics concerning MUX Multiplexing Institution in 11 provinces in Indonesia. These occurrences should be a lesson and one-hit punch for the government in regulating digital broadcasting.

Second, MUX management should be entirely delegated to the government, in this case, as the Public Broadcasting Institution (Television of the Republic of Indonesia or Radio of the Republic of Indonesia). This opinion is an antithesis of the first opinion that suggests multi MUX (Networked Private Broadcasting Institution becomes MUX manager). To be fair, MUX should be managed by the Public Broadcasting Institution (Television of the Republic of Indonesia or Radio of the Republic of Indonesia) as a 
representation of the state-owned broadcasting institution. All this time, the digital channel belongs to the public and it should be returned to the public. The Public Broadcasting Institution is appropriate to run this business function. However, the idea concerning single MUX is strictly confronted as the human resources and technology possessed by Public Broadcasting Institution have a lot of issues, one of which is human resources in those institutions are close to retirement. The lack of young workforces to manage the Public Broadcasting Institution causes public distrust in the single MUX system.

The third opinion emerges as an alternative by combining two opinions, in which MUX management is delegated both to networked Private Broadcasting Institution and Public Broadcasting Institution. The opinion that is later known as hybrid MUX receives positive response and acceptance from all parties. However, the failure in releasing new regulation and the revision of Law No. 32/2002 on Broadcasting cause the absence of a formidable legal basis in digital broadcasting business practice.

According to the study by Hutabarat (2014, p. 493), the most profitable digital broadcasting management business model is a business model that divides content and network operator. From the aspect of the content operators, the cost is smaller because broadcasting infrastructure development is entirely borne by the network operator. In addition, transmission equipment jointly used by many content operators is efficient in layout and resource consumption. This is relevant to the information of Deddy Risnanto from the Association of Indonesian National Television (2020) that the government will determine the MUX rental price of digital television in Jakarta. MUX rental price of networked television and local television is set to one price at 44 million rupiahs per month for $2 \mathrm{MB}$ of capacity (or 528 million rupiahs per year). This price is lower compared to renting a tower that costs around 2 billion rupiahs per year.

The publication of Job Creation Law No. 11/2020 offers a new hope (though not optimally) to become a new legal basis concerning digital broadcasting regulation in general, despite it is not specially designed to regulate the digital broadcasting industry. This is because the regulation only amends Law No. 32/2002 on Broadcasting.

Specifically, Law No. 11/2020 on Job Creation regulates Broadcasting only in Chapter III Article 72. Accordingly, this article amends Law No. 32/2002 on Broadcasting by revoking Article 34, inserting Article $60 \mathrm{~A}$, and amending six articles consisting of Article 16 paragraph 1 and 2; Article 25 paragraph 1 and 2, Article 33 paragraph 1, 2, and 3; Article 55 paragraph 1, 2, and 3; Article 55 paragraph 1 and 2; and Article 58 paragraph 1 and 2.

The Law of the Republic of Indonesia No. 11/2020 cannot be technically operationalized before the publication of Government Regulation concerning Guidelines for Digital Broadcasting Implementation and the derivative regulations. This is because it takes a long time. Furthermore, some elements have filed a judicial review against Law No. 11/2020 concerning Job Creation to the Supreme Court, which harms the public.

The government, in this case, the Minister of Communication and Informatics of the Republic of Indonesia, should not rush in providing policies regarding digital broadcasting before the legal basis that regulates digital broadcasting is clear, accomplished, and comprehensive. Unfortunately, during this period, the Decree of the Minister of Communication and Informatics seems haphazard, which is detrimental to the public; if the legal basis is repealed, entrepreneurs of the broadcast media business have the potential to suffer losses since they have invested heavily in digital technology. 
In reality, several digital television stations have already broadcasted actively. However, currently, there is no formidable legal basis. This means the Law of the Republic of Indonesia No. 11/2020 on Job Creation is not or has not become strong legal protection to regulate digital broadcasting. Digital broadcasting issues at this time and in the future, philosophically, will become a legal convergence between digital broadcasting technology, digital telecommunication technology, internet technology, and content providers' creativity. Meanwhile, Job Creation Law No. 11/2020 (1.187 pages) mentions broadcast around 40 times, telecommunication for 62 times, and internet for two times. Quantitatively, broadcasting is not a national strategic issue at this time.

The followings are the list of broadcasting media regulations (analog and digital) that are relevant to be understood by researchers and academics: Law of the Republic of Indonesia No. 11/2020 on Job Creation: Law of the Republic of Indonesia No. 40/1999 on Press; Law of the Republic of Indonesia No. 32/2002 on Broadcasting; Law of the Republic of Indonesia No. 33/2009 about Film; Law of the Republic of Indonesia No. 36/1999 on Telecommunications; Law of the Republic of Indonesia No. 44/2008 on Pornography; Law of the Republic of Indonesia No. 19/2016 on Amendments of Law of the Republic of Indonesia No. 11/2008 on Information and Electronic Transactions; Law of the Republic of Indonesia No. 14/2008 about Public Information Transparency; Government Regulation of the Republic of Indonesia No. 11/2005 on Broadcasting Administrations of Public Broadcasting Institutions; Government Regulation of the Republic of Indonesia No. 12/2005 on Public Broadcasting Institution Radio of the Republic of Indonesia; Government Regulation of the Republic of Indonesia No. 13/2005 on Public Broadcasting Institution Television of the Republic of Indonesia; Government Regulation of the Republic of Indonesia No. 50/2005 on Broadcasting Administrations of Private Broadcasting Institution; Government Regulation of the Republic of Indonesia No. 51/2005 on Broadcasting Administrations of Community Broadcasting Institutions; Government Regulation of the Republic of Indonesia No. 52/2005 about Broadcasting Administrations of Subscription-based Broadcasting Institutions.

The regulations also include Regulation of the Minister of Communication and Informatics No. 3/2019 about Implementation of Simulcast in the framework of Migration Preparation from Analog to Digital Television Broadcasting System; Regulation of the Minister of Communication and Informatics No. 4/2019 on Technical Requirements of Telecommunication Tools and Equipment for Radio and Television Broadcasts Administration. Regulation of the Minister of Communication and Informatics No. 6/2019 on Master Plan of Radio Frequency for Digital Terrestrial Television Broadcasting Implementation on Ultra High-Frequency Radio; Regulation of the Minister of Communication and Informatics No.13/2018 on Allocation Table of Radio Frequency Spectrum in Indonesia; Regulation of the Minister of Communication and Informatics No. 5/2016 on Trials of Telecommunication, Informatics and Broadcasting Technology; Regulation of the Minister of Communication and Informatics No. 32/2013 on Implementation of Digital Television Broadcasting and Multiplexing Broadcasting via Terrestrial System; Regulation of the Minister of Communication and Informatics No. 22/PER/M.KOMINFO/11/2011 on Free-To-Air Digital Terrestrial Television Broadcasting Administration, in which this regulation is revoked by the Supreme Court of the Republic of Indonesia; Regulation of Indonesian Broadcasting Commission No. 01/P/KPI/03/2012 on Broadcasting Behavior Guideline; 
Regulation of Indonesian Broadcasting Commission No. 02/P/KPI/03/2012 on Broadcasting Program Standards; Regulation of Press Council No. 6/PeraturanDP/V/2008 on Ratification of the Decree of Press Council No. 03/SK-DP/III/2006 on Journalistic Code of Ethics as Press Council Regulation); Government Regulation of the Republic of Indonesia No. 109/2012 on Protecting Materials that Contain Additive Substance in Tobacco Products in the Interests of Health; Government Regulation of the Republic of Indonesia No. 19/2003 on Protecting Cigarettes in the Interests of Health; Regulation of the Minister of Health No. 1787/MENKES/PER/XII/2010 on Health Service Ads and Publications; and other derivative regulations.

Based on studies of the aforementioned regulations, the legal notes are as follows. First, there is no legal protection to regulate the digital broadcasting business until today. Second, the issuance of Law No. 11/2020 on Job Creation cannot be relied on to regulate digital broadcast media business. This is because the new regulation only rectifies (revoke, insert, and amend) eight articles of Broadcasting Law No. 32/2002. Therefore, it means the Broadcasting Law of the Republic of Indonesia No. 32/2002 remains valid with eight amended articles.

Law of the Republic of Indonesia No. 11/2020 on Job Creation mentions neither Multiplexer (MUX) management policy nor regulation of position and relation among digital Public Broadcasting Institutions, digital Private Broadcasting Institutions, and digital Subscription-based Broadcasting Institutions, Community Broadcasting Institutions, and other crucial issues. Therefore, the public's expectation for completing the revision of Broadcasting Law No. 32/2002, which was awaited until the end of 2019, could not be realized. However, if the revision were successful, digital broadcasting regulation would be available.

Although the House of Representatives of the Republic of Indonesia has expended a huge amount of State Budget since 2007-2019 to arrange revision material of Broadcasting Law No. 32/2002, it is to no avail. Even in 2020, the House of Representatives does not include the Revision of Broadcasting Law No. 32/2002 into Priority National Legislation Program. Therefore, the regulation is unlikely to be realized at the end of 2020. Moreover, member replacement of the House of Representatives for the election period of 2004, 2009, 2014, and 2019 disperses the continuity of revision material discussion for Broadcasting Law No. 32/2002. As a consequence, the revision failed miserably. Therefore, can the public expect that, in 2021, the revision of Law No. 32/2002 on Broadcasting able to create a new regulation in the digital broadcasting industry?

The public has been tired of hoping for the progress of the People's Representatives in bringing out the revision of Law No. 32/2002. On the contrary, the government's spirit, in this case, the Minister of Communication and Informatics, is very progressive in yielding digital broadcasting regulation. However, this action is considered too haphazard and impulsive as it issues digital broadcasting regulation while legal protection is not yet available (Law on Digital Broadcasting).

For instance, the Minister of Communication and Informatics of the Republic of Indonesia rushed to issue the Regulation of the Minister of Communication and Informatics No. 5/2016 on Trials of Telecommunication, Informatics, and Broadcasting Technology. This regulation becomes a legal basis for implementing digital broadcasting. However, it is still in a trial phase conducted by the Television of the Republic of Indonesia collaborating with Private Broadcasting Institutions in Indonesia.

Next, the Minister of Communication and Informatics of the Republic of 
Indonesia issued Regulation of the Minister of Communication and Informatics No. 3/2019 on the Implementation of Simulcast Broadcasting in the framework of Migration Preparation from Analog Television Broadcasting System to Digital Television Broadcasting System. Later, it is followed by the issuance of Regulation of the Minister of Communication and Informatics No. 6/2019 on Master Plan of Radio Frequency for the Interest of Digital Terrestrial Broadcast Television Administration on Ultra High Radio Frequency. Before this, the Ministry's haphazard action to issue Regulation of the Minister of Communication and Informatics No. 22-PER-M.KOMINFO-11-2011 on Free-To-Air Digital Terrestrial Television Broadcasting Administration has triggered national turmoil. The Supreme Court eventually revoked this regulation through Decree of the Supreme Court of the Republic of Indonesia No. 38 P/HUM/2012 and Decree No. $40 \mathrm{P} / \mathrm{HUM} / 2012$. Even worse, the Minister of Communication and Informatics has stipulated 33 decrees on the Stipulation of Multiplexing Broadcasting Operators and Free-To-Air Digital Terrestrial Television Broadcasting Operators in various service zones in Indonesia. In fact, as mentioned in the previous section in trial No. 119/G/2014/PTUN-JKT; on 5 March 2015, the Civil Court of Jakarta has revoked 33 Decrees of the Minister of Communication and Informatics on MUX Multiplexing Institutions in 11 provinces in Indonesia. This occurrence should be a lesson and onepunch hit for the government in regulating digital broadcasting.

Second, as of this moment (read: on 3 January 2021), there is no regulation to be a technical guideline to implement the mandate of Law No. 11/2020 on Job Creation, especially Article 60A paragraph 1-3, due to the absence of controlling Government Regulation. Moreover, the definition of broadcasting complies with its definition as referred to in Law No. 32/2002 on Broadcasting Article 1 paragraph 2, in which it only refers to analog frequency broadcast. Therefore, Job Creation Law No. 11/2020 can only be executed when the Government Regulation on the Implementation of Post, Telecommunication, and Broadcast Sector has been issued. Until early January 2021, the questioned Government Regulation was in the process of harmonization and finalization.

Third, the step of the Minister of Communication and Informatics to issue regulations on digital broadcasting from December 2002 until 1 November 2020, whilst there is no specific regulation on digital broadcasting, may backfire and potentially inflict a financial loss among investors or broadcast media industry administrators. This is because they have invested heavily in digital broadcasting technology. However, the policy on digital broadcasting is then altered because of the negligence of policyholders (in this context is the Ministry of Communications and Informatics) in formulating and issuing regulations that surpass the Law of the Republic of Indonesia, as with legal case regarding the issuance of Regulation of the Minister of Communication and Informatics No. 22/PER/M.KOMINFO/11/2011 on Free-To-Air Digital Terrestrial Television Broadcasting Implementation. This regulation is revoked by the Supreme Court.

\section{The practice of Broadcast Media Business in Indonesia: The Conflict of Simulcast Broadcasting Models (Analog and Digital), Internet-Based Broadcasting, and Social Media-Based Broadcasting}

To this date, several networked television stations (both public and private) have already broadcasted in digital and analog channels simultaneously (simulcast). According to data from the Association of Indonesian Digital Broadcasting Televisions, 108 holders of the Broadcasting Operational License have been issued by the Ministry of Communication and Informatics of the Republic of Indonesia. Furthermore, based on 
Regulation of the Minister of Communication and Informatics No. 5/2016 on Trials of Telecommunication, Informatics, and Broadcasting Technology, a trial run for digital television broadcasting was carried out by preparing Television of the Republic of Indonesia to collaborate with 36 broadcasting companies from 15 June, 2016, to 15 June, 2017, in 17 capitals of provinces in Indonesia. As a result, it has been recorded that 14 television stations have possessed Broadcasting Operational License consisting of 12 stations for digital broadcasting and two stations for analog broadcasting.

The list of digital broadcasting television stations includes Nusantara TV, Inspira TV, Kompas TV, Gramedia TV, Tempo TV, NET TV, CNN TV, TV Muhammadiyah, Merah Putih TV, Badar TV, and Tegar TV (Association of Indonesian Digital Broadcasting Televisions, 2017: Abdullah, 2020). In addition, to this date, not only do most networked private television stations broadcast in analog-terrestrial format, but they also broadcast in digital format. Before the issuance of Law No. 11/2020 on Job Creation, the practice of digital broadcasting is based on four main regulations, namely: Regulation of the Minister of Communication and Informatics No. 3/2019 on Simulcast Broadcasting Implementation in the framework of Migration Preparation from Analog to Digital Television Broadcasting System; Regulation of the Minister of Communication and Informatics No. 6/2019 on Master Plan of Radio Frequency for the Interest of Digital Terrestrial Television Broadcasting Implementation on Ultra High Frequency; Regulation of the Minister of Communication and Informatics No. 5/2016 on Trials of Telecommunication, Informatics, and Broadcasting Technology; and Regulation of the Minister of Communication and Informatics No. 32/2013 on Implementation of Digital Television Broadcasting and Multiplexing Broadcasting via Terrestrial System.

The Broadcasting Law of the Republic of Indonesia No. 32/2002 does not regulate digital broadcasting. It means the law is only based on three regulations at the ministerial level, which is frail. It also indicates that the step of the Minister of Communication and Informatics to issue a broadcasting license to several analog television stations and digital broadcasting stations to broadcast in digital format is mere gambling. This action is prone to lawsuits from any direction because the policy is not based on Law. As evidence, the Ministry of Communication and Informatics was once sued by a journalist association or injured parties resulted from the issuance of the Decree of the Minister of Communication and Informatics. This incident should be a meaningful legal lesson for the government.

Based on data from the Ministry of Communication and Informatics of the Republic of Indonesia (2020), analog television broadcasts cannot reach as many as 293 regencies. Meanwhile, as many as 221 regencies can be reached by an analog television broadcast. Therefore, blank spots are greater in number than analog broadcast-reachable spots. Reviewed from the number of television stations in Indonesia, there are 728 stations (consisting of 1 Public Broadcasting Institution, 20 Local Public Broadcasting Institutions, 18 Community Broadcasting Institutions, and 689 Private Broadcasting Institutions; the least mentioned is categorized into 487 Networked Station System and 202 Non-Networked Station System). This means the Networked Station System broadcasting model is more dominating than the Non-Networked Station system model. The reason is that the Networked Station System is more efficient and productive, unlike Non-Networked Station System that is difficult to survive.

Not only does the media business in Indonesia broadcast in analog and digital channels by utilizing satellite and frequency technology, but it also utilizes the internet 
and social media. The latest digital broadcasting technology is not regulated in law, including in the new regulations (Law No. 11/2020 on Job Creation). Internet-based digital broadcasting technology (also known as television streaming and radio streaming) as well as social media-based digital broadcasting, such as YouTube, Instagram TV, Facebook TV, and so forth allow the media business to carry out live streaming. Television streaming can be accessed in various applications as follows: https://www.useetv.com, https://www.vidio.com, https://www.mivo.com, and so forth.

Currently, the number of internet users in the world is 4.9 billion people. YouTube as one of the social media platforms has more than 8.5 billion users; Facebook is accessed by more than 2.7 billion users; Instagram has 144 million users, and Twitter is used by more than 367 million active users (Stats, 2020). It is confirmed that all television stations in Indonesia broadcast not only in digital and analog channels using frequency medium but also on the internet and social media channels. Moreover, most YouTubers do not represent certain companies or institutions as their Youtube is a form of interpersonal business. Artists, lecturers, students, content creators, and other professions utilize YouTube as an effective broadcast medium to attract attention from viewers and advertisers. In the context of YouTube commodification, the number of viewers is an absolute requirement for YouTubers to gain earnings and advertisements as an effect of monetizing.

To this date, internet-based and social media-based digital broadcastings encounter the absence of regulation. There are no regulations over many aspects, such as business model management, how many accounts should YouTubers have at maximum, codes of ethics of broadcasting in social media, tax model borne by YouTubers, content supervision models in social media, and the legality of YouTubers with a foreign country domain but showing contents produced in Indonesia or vice versa.

Law of the Republic of Indonesia No. 11/2020 on Job Creation and Law of the Republic of Indonesia No. 32/2002 on Broadcasting do not regulate internet-based and social media-based digital broadcasting. Worse, Indonesia does not have a good and proper blueprint for digital broadcasting. Therefore, it makes sense if the national broadcasting policies keep changing and being delayed from the target. Moreover, every leadership changeover at the executive level (both president and ministers) evokes different policies in response to the implementation of digital broadcasting. Indeed, the Ministry of Communication and Informatics of the Republic of Indonesia has determined a digital television infrastructure roadmap to implement migration from analog to digital television broadcasting systems in Indonesia. The arrangement of this roadmap has begun since the beginning of 2009 until 2018.

As regulatory support for the implementation of digital television broadcasting, the government, in 2009, stipulated Regulation of the Minister Communication and Informatics No. 39/2009 on Basic Framework of the Implementation of Free-To-Air Digital Terrestrial Television Broadcasting. This regulation is a basic framework of how to implement digital television broadcasting. In November 2011, the government issued Regulation of the Minister of Communication and Informatics No. 22/2011 on Implementation of Free-To-Air Digital Terrestrial Television Broadcasting as a substitute of Regulation of the Minister of Communication and Informatics No. 39/2009. However, this regulation failed as it was sued by the Association of Indonesian Networked Television and the Association of Indonesian Local Television. The ordinance regulates the business model of digital television broadcasting, multiplexing 
broadcast service zone, Domestic Component Level for the production of Set-Top Box, and digital television broadcasting implementation.

Other activities include: multiplexing broadcast implementation selection (JuneJuly 2012); the Decree has been revoked by the Civil Court of Jakarta, the stipulation of digital television licensing regulation, infrastructure network deployment for digital television multiplexing in each service zone, simulcast implementation (in which analog and digital television broadcasting are carried out simultaneously) and analog switch-off (switching off analog broadcasting to be replaced with digital broadcasting) (Indonesia, 2013).

The numbers of television stations are as many as 395 private broadcasting institutions, 151 subscription broadcasting institutions, and 3 community broadcasting institutions; as well as radio stations of 1,100 private broadcasting institutions and 23 community broadcasting institutions (Susanto et al., 2016, pp. 56-58), it is a big step for this nation to implement a digital broadcasting policy. Through this step, the establishment of new digital television and radio stations will provide a lot of job opportunities for many media workers. Nevertheless, on the other hand, if it is misused, it will only further perpetuate the interests of entrepreneurs and authorities.

The government's plan to completely migrate from analog to digital (Analog Switch Off/ASO) in 2013 was failed or delayed. Analog Switch-Off Plan at the end of 2018 was also unsuccessful. Currently, Analog Switch Off in Indonesia is scheduled for November 2022. The opportunity for another delay in Analog Switch Off implementation is wide-open, considering digital broadcasting issues are quite complex. A tug-of-war between the House of Representatives, the government, the broadcasting industry, and dynamic society becomes the final determinant. Amid the domination of ownership of various media companies by several conglomerates, MUX management arrangements tend to be controlled by the owners of capital who are close to the center of power. In fact, the management of national private television in Indonesia is currently excessive and centralized (Rianto, 2014, pp. 19-20; Siregar, 2014, pp. 147-151).

The era of disruption marked by $3 \mathrm{~S}$ (Speed, Surprises, Sudden Shift) resulted in massive changes to business models, lifestyles, regulations, and paradigms (Kasali, 2018, pp. 459-460). Digital broadcasting is an era of disruption which is a necessity for this nation. The issuance of Law No. 11/2020 on Job Creation on 2 November, 2020, must be followed up with Government Regulation on Implementation of Post, Telecommunication and Broadcasting Sectors; or derivative regulations. The lack of technical regulations; the above regulations complement Law No. 32/2002 on Broadcasting and Law No. 11/2020 on Job Creation; cannot be executed. Internet-based and social media-based digital broadcastings have not yet been regulated by law. The lack of regulations becomes a major issue now and in the future. Potentially triggering conflict of business interests between institutions of frequency-based digital broadcasting and internet-based and social media-based digital broadcasting as they compete for the same market segments and advertisers. A lawsuit in progress filed by MNC Group against broadcasting definition contained in Broadcasting Law No. $32 / 2002$ in the Constitutional Court is a legal fact of the potential conflict. In the researcher's view, internet-based and social media-based broadcastings will have a powerful influence on the broadcasting industry. Therefore, its position is very strategic. At the same time, it explains why most analog broadcasting television stations also broadcast on YouTube channels and other social media platforms.

Analysis regarding internet-based and social media-based digital broadcastings is 
limited, including this research. In the future, there should be more initiatives to intensify research topics related to this issue. Furthermore, frequency, internet, and social media-based digital broadcastings should be utilized for public interests instead of enriching assets owned by broadcast media companies and owners.

A study conducted by Manggut (2019, p. 22) affirmed that in this digital era, media managers need to understand the power of technology platforms and the patience of capital owners rather than showing off power or romance. On the other hand, changes to digital broadcasting policies must be accompanied by an awareness of people's behavior in accepting these changes, both in terms of technology and behavior (Sari, 2015, pp. 228-230).

Diversity of ownership principal must be reinforced to prevent media ownership monopoly. In addition, diversity of content must be applied to prevent content uniformity that might threaten broadcasting democratization and the diversity of locality to prevent Jakarta-centric program, foreign program dominations, and diversity of audienceship/aedileship.

In the practice of analog broadcasting business so far, there are five dominant things that occur. First, broadcast media ownerships are only controlled by 13 mass media entrepreneurs (Lim, 2012, pp. 2-3; Nugroho et al., 2012, p. 39), which currently direct to 3-4 major media corporates. If left unchecked, it will create a media monopoly (Kristiawan, 2013, pp. 141-150; Nainggolan, 2018, p. 781; Rianto, 2012, pp. 84-87; Supadiyanto, 2018, pp. 5-9; Syahputra, 2013, pp. 150-152). Second, local programs are aired at a minimum quantity in various networked local broadcasting stations (Supadiyanto, 2015, p. 76). Third, foreign programs consisting of films and entertainment dominate broadcast programs of networked television stations. Fourth, the Subscription-based Broadcasting Institution is nearly unmonitored by the Indonesian/Regional Broadcasting Commission, considering its limitation. Fifth, various television and radio stations have already broadcasted in digital format (either using frequency, internet, or social media), but the controlling regulations have not yet entirely regulated this matter. Sixth, the authority of the Indonesian Broadcasting Commission seems weak (Doly, 2013, pp. 220-221). Control in the management of broadcasting institutions in Indonesia is still dominated by the government through the Ministry of Communication and Information of the Republic of Indonesia.

Research on social media and Internet-based broadcasting is rarely produced in Indonesia. Therefore, this is an opportunity for other researchers to work on it so that they can produce innovations and new strategies in developing the world of broadcasting in Indonesia that is more progressive and pro-people.

\section{Conclusion}

First, analog and digital broadcasting law maps in Indonesia remain overlapping. Since the issuance of Law No. 32/2002 on Broadcasting (on 28 November 2002) until 1 November 2020, the absence of regulation occurs in digital broadcasting as the government still relies on Broadcasting Law No. 32/2002 that only covers analog. The Ministry of Communication and Informatics fulfills the absence of regulation by issuing some regulations at the ministerial level which control digital broadcasting. With such a legal basis, various trials of digital broadcasting are carried out. However, the Ministry's policy to issue Regulations of the Minister of Communication and Informatics on digital broadcasting does not work effectively. The issued regulations were sued by the Association of Indonesian Network Television and Association of 
Indonesian Local Television. The regulations were eventually revoked by the Supreme Court for the sake of the law. Even the Civil Court of Jakarta repealed 33 Decrees of the Minister of Communication and Informatics on Stipulation of Multiplexing Broadcast Institutions on Free-To-Air Digital Terrestrial Television Broadcast Administrator in service zone 1, 4, 5, 6, 7, 14, and 15. This means Job Creation Law No. 11/2020 is the only main legal protection in implementing digital broadcasting. Meanwhile, the broadcasting definition is still based on Law No. 32/2002 that only covers analog broadcasting. Until this research is completed (15 December 2020), Government Regulation on Implementation of Post, Telecommunication and Broadcasting Sectors to carry out Law No. 11/2020 on Job Creation, especially Article 60A, is in the process of arrangement.

Besides, there are 5 other regulations at the ministerial level (Regulation of the Minister of Communication and Informatics No. 3/2019 on Implementation Simulcast Broadcasting in the framework of Migration Preparation from Analog to Digital Television Broadcasting, Regulation of the Minister of Communication and Informatics No. 4/2019 on Technical Requirements of Telecommunication Tools and Equipment for Radio and Television Broadcasts Administration, Regulation of the Minister of Communication and Informatics No. 6/2019 on Master Plan of Radio Frequency for the Interest of Digital Terrestrial Television Broadcasting Implementation on Ultra High Frequency Radio, Regulation of the Minister of Communication and Informatics No. $5 / 2016$ on Trials of Telecommunication, Informatics and Broadcasting Technology; Regulation of the Minister of Communication and Informatics No. 32/2013 on Implementation of Digital Television Broadcasting and Multiplexing Broadcasting via Terrestrial System) which the foundation of legal formation is based on Law No. $32 / 2002$ on Broadcasting (analog). It means there is an anomaly in its legal logic. Of course, it becomes a legal problem at present and in the future.

Second, from 2008 until 2020, the government has applied digital broadcasting policies (in forms of trial for limited digital broadcasting) and simulcast policy by allowing television stations to broadcast in analog and digital channels simultaneously and stipulating Analog Switch Off. The legal foundation is merely based on Law No. $32 / 2002$ on Broadcasting (analog). The government bases only on five regulations, as previously mentioned in the first conclusion. Therefore, an absence of regulations occurs in digital broadcasting. The issuance of Law No. 11/2020 on Job Creation that revises 8 Articles of Law No. 32/2002 on Broadcasting (analog) truly cannot be used as a legal basis in implementing digital broadcasting. This is because the definition of broadcasting contained by Law No. 11/2020 on Job Creation still uses terminology or definition contained by Law No. 32/2002 on Broadcasting (analog) Article 1 paragraph 2. This indicates inconsistency. It has been clear that the formulation of 8 Articles in Law No. 11/2020 on Job Creation related to Post, Telecommunication and Broadcasting, in relation with Law No. 32/2002 on Broadcasting, is made in a hurry. The study by Harjessi and Huseini (2019, p. 145) suggested that to prevent failure in implementing digital broadcasting policies, interested parties should be involved to harmonize perception, planning, implementation, and digitization evaluation.

For 13 years (since 2007-2020), the struggle of the House of Representatives in revising Law No. 32/2002 on Broadcasting has expended billions of state budget, yet it is to no avail. Meanwhile, the regulation is expected to be legal protection for digital broadcasting rather than relying on Law No. 11/2020 on Job Creation. 


\section{References}

Abdullah, A. (2020). Pola Kebijakan Digitalisasi Penyiaran di Indonesia. Jurnal Aristo (Social, Politic, Humaniora), 08(1), 76-96.

Armando, A. (2019). Kontestasi dan Negosiasi Kepentingan dalam Implementasi Sistem Siaran Jaringan Televisi di Indonesia. Jurnal Komunikasi, 14(1), 41-60. https://doi.org/10.20885/komunikasi.vol14.iss1.art3

Budiman, A. (2020). Perdebatan Kepentingan Kebijakan Digitalisasi Penyiaran di Indonesia (Studi Kasus Perumusan Kebijakan Digitalisasi Penyiaran pada RUU Penyiaran di DPR 2009-2014 dan 2014-2019) [Interest Disputes of Broadcasting Digitalization Policy in Indonesia]. Politica, 11(1), 107-126. https://doi.org/10.22212/jp.v11i1.1613

Djulaeka, D. dan R. J. (2013). Konvergensi Telematika, Arah Kebijakan dan Pengaturannya dalam Tata Hukum Indonesia. Yustisia, 2(3), 46-60. https://doi.org/10.20961/yustisia.v2i3.10156

Doly, D. (2013). Urgensi Perubahan Undang-Undang No. 32/2002 tentang Penyiaran. Negara Hukum, 4(2), 215-230.

Ernawati, E. and Y. S. N. (2020). Pembatasan Konten Digital pada Media Netflix oleh Komisi Penyiaran Indonesia. Jurnal Perspektif (Kajian Hukum Dan Pembangunan), 25(1), 44-53.

Harjessi, P. N. dan M. H. (2019). Kesiapan Pemerintah dalam Menghadapi Digitalisasi Televisi menurut Perspektif Organisasi Pembelajar. INOVBIZ: Jurnal Inovasi Bisnis, 7, 138-146.

Hutabarat, D. P. (2014). Tinjauan terhadap Model Bisnis Penyelenggaraan Penyiaran TV Digital. ComTech, 5(1), 485-494. https://doi.org/10.21512/comtech.v5i1.2642

Indonesia, K. K. dan I. R. (2013). Peta Jalan Televisi Digital. https://www.kominfo.go.id/content/detail/3262/roadmap-tv-digital/0/tv_digital

Indonesia, K. K. dan I. R. (2020). Sosialisasi dan Publikasi Menjaga Indonesia dan Perbatasan melalui Penyiaran Televisi Digital. https://www.youtube.com/watch? $v=$ RmAgTWSLhlw

Kasali, R. (2018). Disruption (Cetakan 7). PT Gramedia Pustaka Utama.

Kristiawan, R. (2013). Penumpang Gelap Demokrasi (Kajian Liberalisasi Media di Indonesia) (D. U. Maksum (ed.)). Aliansi Jurnalis Independen (AJI) Indonesia.

Lim, M. (2012). The League of Thirteen: Media Concentration in Indonesia (2012th ed.). Participatory Media Lab at Arizona State University and Ford Foundation. http://www.public.asu.edu/ mlim4/files/Lim_IndoMediaOwnership_2012.pdf

Mahfud, M. (2017). Politik Hukum di Indonesia (Cetakan 7). PT Rajagrafindo Persada.

Manggut, W. (2019). Meretas Kembali Jalan Jurnalisme di Era Digital. Jurnal Dewan Pers, 20(November), 18-22.

Maulana, N. M. (2019). Menggali Kebijakan Penyiaran Digital di Indonesia. Jurnal Ilmu Komunikasi, 17(1), 60-72. https://doi.org/10.31315/jik.v17i1.2332

Maulana, N. M. dan N. H. (2019). Implementasi Teori Fungsional Struktural dalam Regulasi Penyiaran Digital di Indonesia. Jurnal Sosioteknologi, 18(2), 179-190. https://doi.org/10.5614/sostek.itbj.2019.18.2.3

Nainggolan, B. (2018). Dinamika Konsentrasi Pasar Industri Pertelevisian Nasional. Jurnal ASPIKOM, 3(4), 767-782.

Nugroho, Y., Putri, D. A., \& Laksmi, S. (2012). Mapping the Landscape of the Media Industry in Contemporary Indonesia. In Report series: Engaging Media, Empowering Society: Assessing media policy and governance in Indonesia 
through the lens of citizens' rights (Issue March). Centre for Innovation Policy and Governance; Hivos; Manchester Business School; dan Ford Foundation.

Ramli, A. M. (2008). Dinamika Konvergensi Hukum Telematika dalam Sistem Hukum Nasional. Jurnal Legislasi Indonesia, 5(4), 1-11.

Undang-Undang RI No. 32/2002 tentang Penyiaran, (2002).

Rianto, P. dkk. (2012). Digitalisasi Televisi di Indonesia (Ekonomi Politik, Peta Persoalan, dan Rekomendasi Kebijakan) (2012th ed.). PR2 Media dan Yayasan TIFA. http://pr2media.or.id/portfolio/digitalisasi-tv-di-indonesia/

Rianto, P. dkk. (2014). Kepemilikan dan Intervensi (Perampasan Hak Publik, Dominasi, dan Bahaya Media di Tangan Segelintir Orang) (I. Poerwaningtias (ed.); 2014th ed.). PR2Media dan Yayasan Tifa Indonesia.

Risnanto, D. (2020). Materi Webinar: Digitalisasi Televisi: Peluang dan Tantangan.

Riyanto, M. (2019). Arah Revisi Undang-Undang Penyiaran dalam Perspektif Hukum Ekonomi. Jurnal Spektrum Hukum, 16(1), 60-74.

Sari, D. (2015). Pengaruh Faktor-Faktor Penerimaan Masyarakat pada Masa Simulcast Free to Air TV Digital Factors Affecting the Acceptance of Simulcast Free to Air Digital Broadcasting. Jurnal Penelitian Pos dan Informatika, 5(2), 213-232. https://doi.org/10.17933/jppi.2015.050200

Siregar, A. E. (2014). Mengawal Demokratisasi Media: Menolak Konsentrasi Membangun Keberagaman (2014th ed.). Penerbit Buku Kompas.

Stats, I. L. (2020). Internet Live Stats. Internet Live Stats. https://www.internetlivestats.com/

Sumiaty, N. (2012). Konstruksi Regulasi Penyiaran di Era Konvergensi. Jurnal Penelitian Komunikasi, 15(2), 205-223. https://doi.org/10.20422/jpk.v15i2.715

Supadiyanto. (2015). Implementasi Program Siaran Lokal pada Stasiun Televisi di DIY. Jurnal AN-NIDA, 7(2), 65-78. https://ejournal.unisnu.ac.id/JKIN/article/view/749

Supadiyanto. (2018). Konglomerasi Media dalam buku: Masa Depan Indonesia Bangkit atau Bangkrut! In Sukarno \& F. Annisya (Eds.), Masa Depan Indonesia Bangkit atau Bangkrut! (2018th ed., pp. 5-9). Sukarno Pressindo.

Susanto, A., Sari, D., A, V. H., Prabowo, A., W, R. A., Mahmudah, D., Rahmat, A., Marselita, D., S, R. B., Tribroto, S., \& Hakiki, E. (2016). Buku Putih 2016: Komunikasi dan Informatika Indonesia ( dkk. Sekar, Harjani Retno (ed.)). Puslitbang SDPPPI Badan Penelitian dan Pengembangan SDM Kementerian Komunikasi dan Informatika.

Sutanto, V. W. and S. A. (2015). Menyoal Regulasi Penyiaran Digital (Studi terhadap Kepentingan Publik dalam Regulasi Televisi Digital di Indonesia). Avant Garde, $3(2), 237-249$.

Syahputra, I. (2013). Rezim Media (Pergulatan Demokrasi, Jurnalisme, dan Infotainment dalam Industri Televisi) (Cetakan I). PT Gramedia Pustaka Utama.

Undang-Undang RI No. 11/2020 tentang Cipta Kerja, (2020).

Yuniarto, T. (2019). Masa Depan Jaringan $5 G$ dan Perilaku Komunikasi Digital. Warta ISKI, 2(01), 1-7. https://doi.org/10.25008/wartaiski.v2i01.22 